\title{
Article
}

\section{Self-Compacting Recycled Concrete Using Biomass Bottom Ash}

\author{
Manuel Cabrera ${ }^{1, *(\mathbb{D}) \text {, M. J. Martinez-Echevarria }}{ }^{2}$, Mónica López-Alonso ${ }^{2}$, Francisco Agrela ${ }^{1, *}$ (i) \\ and Julia Rosales ${ }^{1}$ (i) \\ 1 Construction Engineering Area, University of Córdoba, 14071 Córdoba, Spain; jrosales@uco.es \\ 2 Civil Engineering School, University of Granada, 18010 Granada, Spain; mjmartinez@ugr.es (M.J.M.-E.); \\ mlopeza@ugr.es (M.L.-A.) \\ * Correspondence: manuel.cabrera@uco.es (M.C.); fagrela@uco.es (F.A.)
}

Citation: Cabrera, M.

Martinez-Echevarria, M.J.;

López-Alonso, M.; Agrela, F.; Rosales, J. Self-Compacting Recycled Concrete Using Biomass Bottom Ash. Materials 2021, 14, 6084. https://doi.org/ $10.3390 / \mathrm{ma} 14206084$

Academic Editor: Eddie Koenders

Received: 9 September 2021

Accepted: 12 October 2021

Published: 14 October 2021

Publisher's Note: MDPI stays neutral with regard to jurisdictional claims in published maps and institutional affiliations.

Copyright: (c) 2021 by the authors. Licensee MDPI, Basel, Switzerland. This article is an open access article distributed under the terms and conditions of the Creative Commons Attribution (CC BY) license (https:/ / creativecommons.org/licenses/by/ $4.0 /)$.

\begin{abstract}
In recent years, the use of self-compacting concrete has been a great advantage and garnered undoubted interest in construction. Due to the environmental impact caused by the consumption of natural aggregates in the manufacture of concrete, a more sustainable approach is needed. An approach for more sustainable construction is to use industrial waste such as bottom ash from the combustion of biomass as a replacement for natural aggregates. This research aims to use biomass bottom ash as a replacement for natural sand (10\%, 20\% and 30\% replacement); in addition, by utilizing a crushing process of the bottom ash, the ash has been used as a filler replacement (replacement 20\%, 40\% and 60\%). The fresh and hardened properties have been evaluated according to the standard. The results show the feasibility of using biomass bottom ash in self-compacting concrete, providing a sustainable alternative in order to minimise environmental impacts related to the extraction and depletion of natural resources.
\end{abstract}

Keywords: biomass bottom ash; self-compacting concrete; mechanical behaviour

\section{Introduction}

One of the most significant advances in the construction industry has been the development of self-compacting concrete (SCC), also called high-performance concrete by some authors. This type of concrete is known for its excellent deformability and resistance to segregation. It is a type of fluid concrete that does not need to be vibrated or compacted during the pouring process [1]. Many countries have used and adopted this method as a starting point to develop SCC [2-4].

Concrete, in general, has undergone great changes in its dosage to achieve better strengths and obtain better durability. To this end, many studies have included materials such as fly ash [5,6], fly ash with polymers [7], silica fume [8], metakaolin [9] additives, etc.

Although it has been developed with the aim of not needing vibration or compaction, SCC is a recent type of concrete that achieves greater resistance to compression and better durability compared to traditional concrete [10] mainly due to its fine particles, superplasticisers and viscosity modifiers [11,12].

More and more industries related to concrete manufacturing are trying to apply more efficient technologies by optimising existing resources. For a few years, industrial waste of different types has been used after an exhaustive study of its properties for the manufacture of more sustainable concrete for the environment.

Bignozzi and Sandrolini [13] demonstrated the properties of SSC made from recycled tire rubber. Ali and Al-Tersawy [14] used recycled glass to replace fine aggregate in proportions of $0 \%, 10 \%, 20 \%, 30 \%, 40 \%$ and $50 \%$; they showed that recycled glass can be used successfully in SCC manufacturing. Ghernouti et al. [15] studied the properties of SCC that contained waste fibers from plastic bags.

Many studies with industrial waste focus on the use of recycled aggregates from construction and demolition waste. González-Taboada et al. [16] used recycled coarse 
aggregate as a replacement for natural coarse aggregate, Pereira-de-Oliveira et al. [17] studied the permeability of SCC made from recycled coarse aggregate and Kou and Poon [18] reported the fresh and hardened properties of SCC using coarse and fine recycled concrete aggregate.

However, other industrial wastes have not been studied much in the manufacture of SCC, as in the case of ash from biomass combustion. Currently, biomass combustion for electricity generation accounts for $45 \%$ of renewable energy in Spain, generating a volume of residue of 120,000 tons/year [19], of which $64 \%$ corresponds to fly ash, which is the finest fraction carried by combustion gases and is retained in the filters of the combustion chimney; at present, its main use is as a fertiliser in agriculture due to its high content of potassium [20,21]. On the other hand, 36\% corresponds to biomass bottom ash (BBA), and its recovery is currently difficult. There are some studies of the possibility of using BBA as a construction material; for example, it has been incorporated as a substitute for sand or cement [22-25]. The incorporation of BBA has been studied as an aggregate in granular materials treated with cement and in the stabilisation of expansive soils for road subbases [26,27], and some authors reported the use of BBA in conventional concrete [28,29]. However, the use of BBA in self-compacting concrete has not been studied much.

In this context, this research aims to study the mechanical behaviour of self-compacting recycled concrete that incorporates BBA in the replacement of natural sand and crushed BBA as a replacement for natural filler and to determine the effect of its incorporation on its properties in fresh and hardened states. The results obtained can be very significant, both from the point of view of science, which currently does not have much literature, as well as for its practical use due to the reduction in waste, reduction in consumption of natural aggregates and environmental benefits in its application in this type of recycled concrete.

\section{Materials}

The materials that have been used for this type of concrete are those commonly used by companies that produce SCC.

\subsection{Cement}

Ordinary Portland Cement (OPC)(Cementos Portland Valderrivas S.A, Alcalá de Guadaíra, Sevilla, Spain) type I with medium-high resistance $42.5 \mathrm{MPa}$ at 28 days with high initial resistance $\mathrm{R}$ was used (CEM I 42.5-R) according to ASTM C150. Its high initial resistance performance renders it suitable for the manufacture of SCC. As a cement belonging to the CEM I type, it is ideal for the manufacture of precast and prestressed, obtaining high resistance values. The composition is shown in Table 1.

Table 1. Chemical properties of cement. CEM I 42.5-R.

\begin{tabular}{cccccccccc}
\hline \multicolumn{10}{c}{ Content (\%) } \\
\hline $\mathrm{SiO}_{2}$ & $\mathrm{Al}_{2} \mathrm{O}_{3}$ & $\mathrm{FeO}_{3}$ & $\mathrm{Cao}$ & $\mathrm{MgO}$ & $\mathrm{SO}_{3}$ & $\mathrm{~K}_{\mathbf{2}} \mathrm{O}$ & $\mathrm{Na}_{\mathbf{2}} \mathrm{O}$ & $\mathrm{Cl}$ & Loss of Ignition \\
\hline 19.31 & 1.4 & 4.45 & 66.01 & 1.26 & 3.3 & 0.35 & 0.08 & 0.01 & 1.42 \\
\hline
\end{tabular}

\subsection{Limestone Filler $(F)$}

The filler used is a crushed material of a limestone-dolomitic nature supplied by the company "Triturados Puerto Blanco" in Huétor-Santillán (Granada, Spain), and its density is $2.830 \mathrm{~kg} / \mathrm{m}^{3}$. Its grain size is shown in Figure 1, and its specific surface has shown a value of $0.700 \mathrm{~m}^{2} / \mathrm{g}$.

\subsection{Natural Sand (NS)}

The sand is of a limestone-dolomitic nature and is practically free of fines. It comes from the El Rayo quarry, Hermanos Guerrero, Loja (Granada, Spain). 


\subsection{Natural Coarse Gravel (NCG) and Natural Medium Gravel (NMG)}

The aggregates used in the manufacture of concrete have a maximum size of $16 \mathrm{~mm}$, the main properties are shown in Table 2 (Standards used in the experimental work are shown in Appendix A), and their granulometries are shown in Figure 1. The total gravel has been obtained by mixing $4 / 8 \mathrm{~mm}$ medium gravel (NMG) and $8 / 16 \mathrm{~mm}$ coarse gravel (NCG) from the Quintos quarry located in Huétor-Santillán (Granada).

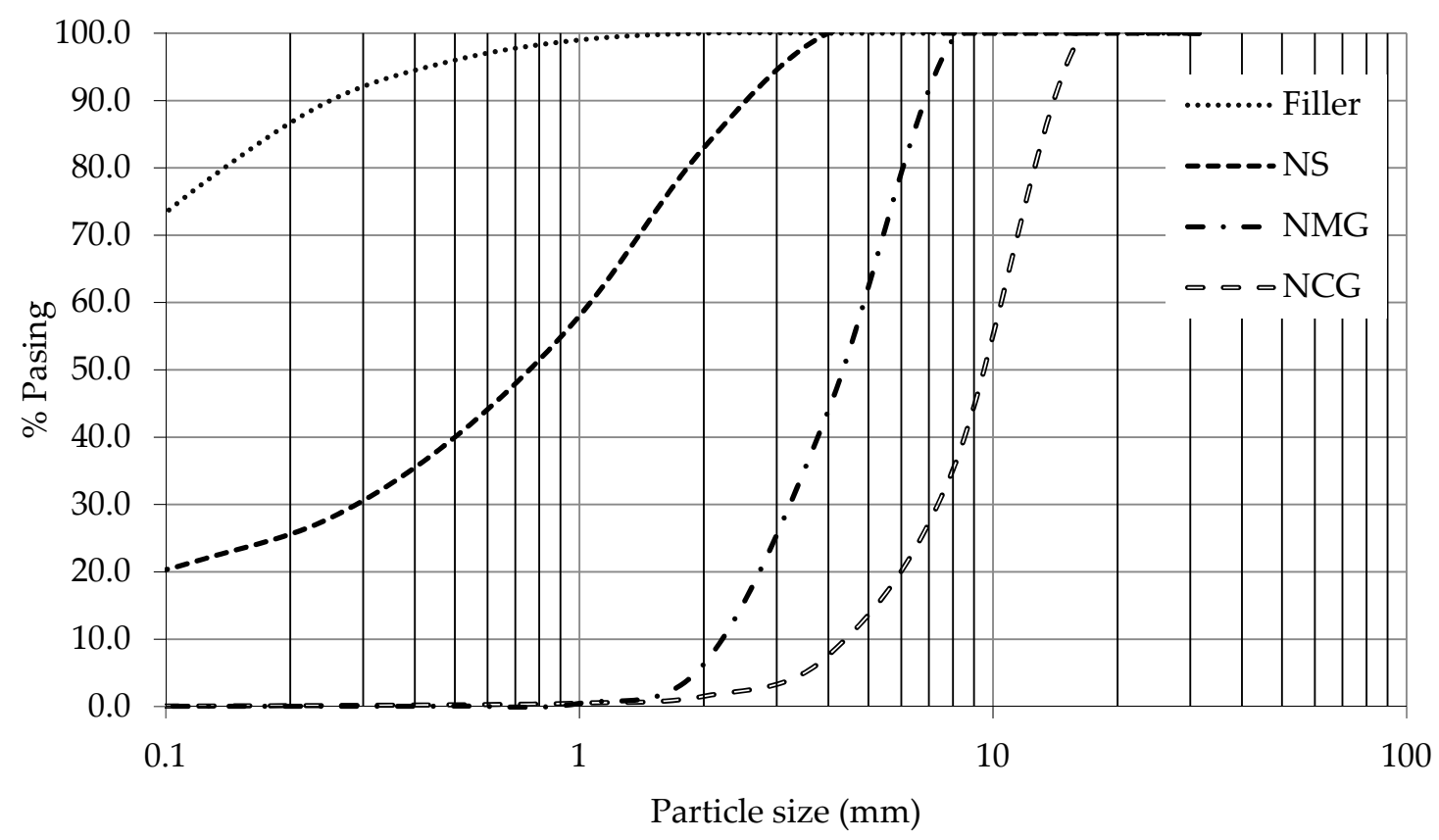

Figure 1. Particle size distribution curve.

Table 2. Physical and chemical properties of natural aggregates and BBA.

\begin{tabular}{|c|c|c|c|c|c|}
\hline PROPERTIES & NS & NCG & NMG & BBA & Test Method \\
\hline Density-SSD $\left(\mathrm{kg} / \mathrm{m}^{3}\right)$ & 2.53 & 2.65 & 2.62 & 1.73 & EN 1097-6: 2014 \\
\hline Water absorption (\%) & 0.9 & 1.59 & 1.63 & 19.83 & EN 1097-6:2014 \\
\hline Los Angeles (\%) & - & 17 & 18 & & \\
\hline Friability ratio $(\%)$ & - & & & 31.8 & 146404: 2018 \\
\hline Sand equivalent (\%) & 85 & - & - & 23 & EN 933-8:2012 \\
\hline Plasticity & Non plastic & Non plastic & Non plastic & Non plastic & EN ISO 17892-12:2019 \\
\hline Chlorides & & & & 0.15 & EN 1774-1:2010 \\
\hline Organic matter \% & & & & 1.51 & UNE 103204:2019 \\
\hline Water-soluble sulphate $\left(\% \mathrm{SO}_{4}\right)$ & $<0.01$ & $<0.01$ & $<0.01$ & 0.32 & EN 1744-1:2010 \\
\hline Acid-soluble sulphate $\left(\% \mathrm{SO}_{4}\right)$ & $<0.01$ & $<0.01$ & $<0.01$ & 0.33 & EN 1744-1:2010 \\
\hline Elemental content $(\%)$ & & & & & EN 196-2:2014 \\
\hline $\mathrm{SiO}_{2}$ & - & - & - & 37.67 & \\
\hline $\mathrm{CaO}$ & - & - & - & 22.03 & \\
\hline $\mathrm{K}_{2} \mathrm{O}$ & - & - & - & 14.06 & \\
\hline $\mathrm{MgO}$ & - & - & - & 5.95 & \\
\hline $\mathrm{Fe}_{2} \mathrm{O}_{3}$ & - & - & - & 2.52 & \\
\hline $\mathrm{Al}_{2} \mathrm{O}_{3}$ & - & - & - & 3.02 & \\
\hline
\end{tabular}

\subsection{Biomass Bottom Ash (BBA)}

This is the coarse fraction produced in the primary combustion chamber due to incomplete combustion (decrease in the melting point) and is made up of most of the mineral fraction of the original biomass [30]. The BBA comes from the biomass power plant called Bioeléctrica de Linares S.L. from the company Sacyr Industrial located in the Linares-Baeza station, Jaén, Spain. 
The fuel supply of the biomass used for the generation of electricity is made up of approximately $40 \%$ olive cake and $60 \%$ biomass of wood (olive, pine and eucalyptus). The BBAs were processed in the laboratory to obtain two different materials used in the manufacture of SCC: BBA (biomass bottom ash kiln-dried for $24 \mathrm{~h}$ and sieved with a particle size no larger than $5 \mathrm{~mm}$ ) and BBA-C (biomass ash kiln-dried for $24 \mathrm{~h}$ and crushed, with a particle size no larger than $0.25 \mathrm{~mm}$ ). The physical and chemical properties of BBA are presented in Table 2.

The physical and chemical characteristics of BBA depend on the types and the different burned biomass used as fuel, in addition to the technology used in the electricity generation plant by burning biomass [31,32].

An important factor in the physical properties of BBAs is their high absorption and low density (19.83\% and $1.73 \mathrm{~g} / \mathrm{cm}^{3}$, respectively). Both parameters are important in the design of mixtures, where the presence of water and the volume of the material are conditioning factors for its manufacture [33].

The friability ratio is an important property from an engineering point of view. A friable material is characterised by the ease of fragmentation of its particles [34]. The BBA has a high coefficient of friability $(31.8 \%)$, but according to the technical specifications (EHE-08) a coefficient lower than $40 \%$ is recommended for the manufacture of concrete, so the BBAs under study are suitable for manufacturing concrete.

The organic matter content in the BBA has shown to be a consequence of the efficiency of the biomass combustion plant [35]; according to other authors, the BBA sample does not present a high percentage of organic content matter [31,32].

Calcium was the main constituent and accounted for $22.03 \%$ by weight (as oxide) of the ash mass. In addition to calcium, BBA is characterised by the relatively high content of potassium ( $14.06 \%$ by weight), the presence of which resulted from the initial content of nutrient ingredients in the olive wood trimmings, in accordance with previous studies [36].

The particle size distribution of the BBA is shown in Figures 2 and 3. Figure 2 shows the grain size curve of the BBA without any processing (BBA-original) and the BBA screened (BBA) to match the grain size of the sand. Figure 3 represents the grain size curve of the crushed BBA (BBA-C) achieving a grain size similar to that of the filler. All the particle size curves have a continuous grain size, thus, guaranteeing a lower percentage of voids in the manufacture of the concrete and optimising the necessary cement paste.

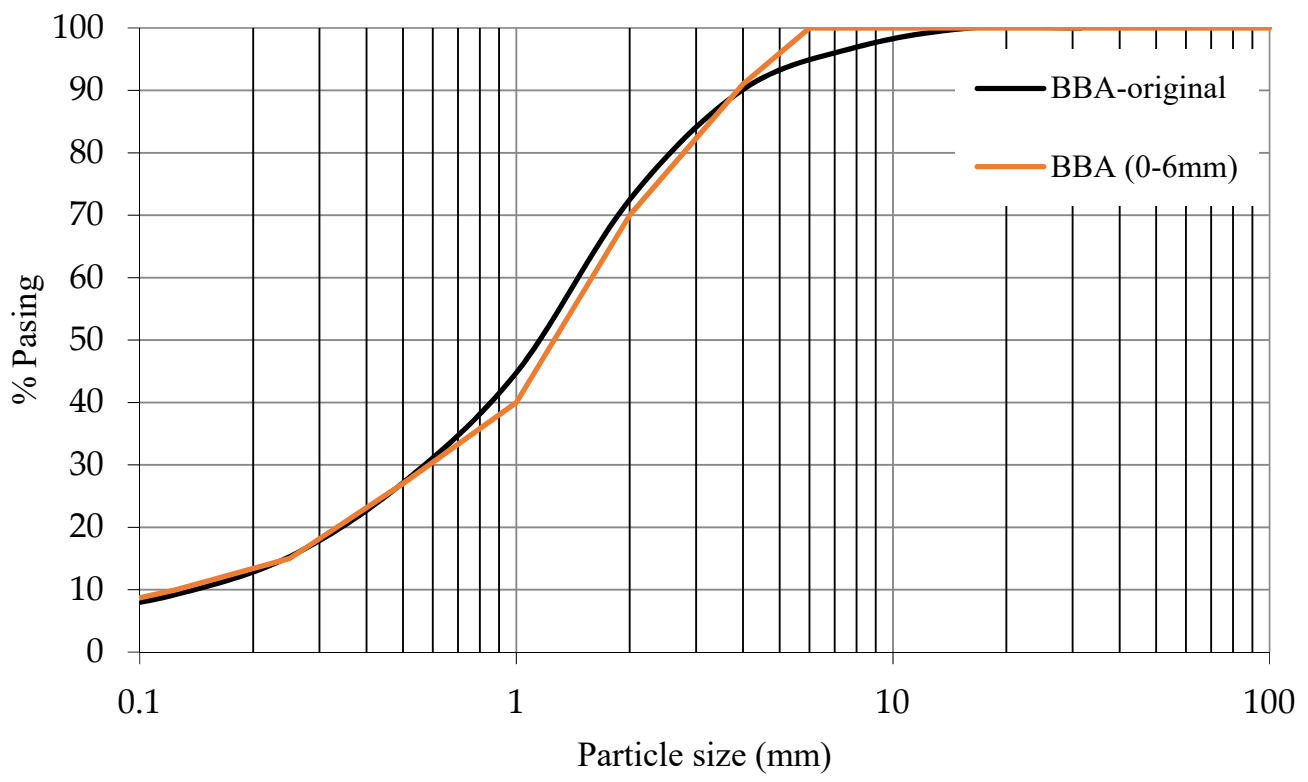

Figure 2. Particle size distribution curve of BBA original and BBA $(0-6 \mathrm{~mm})$. 


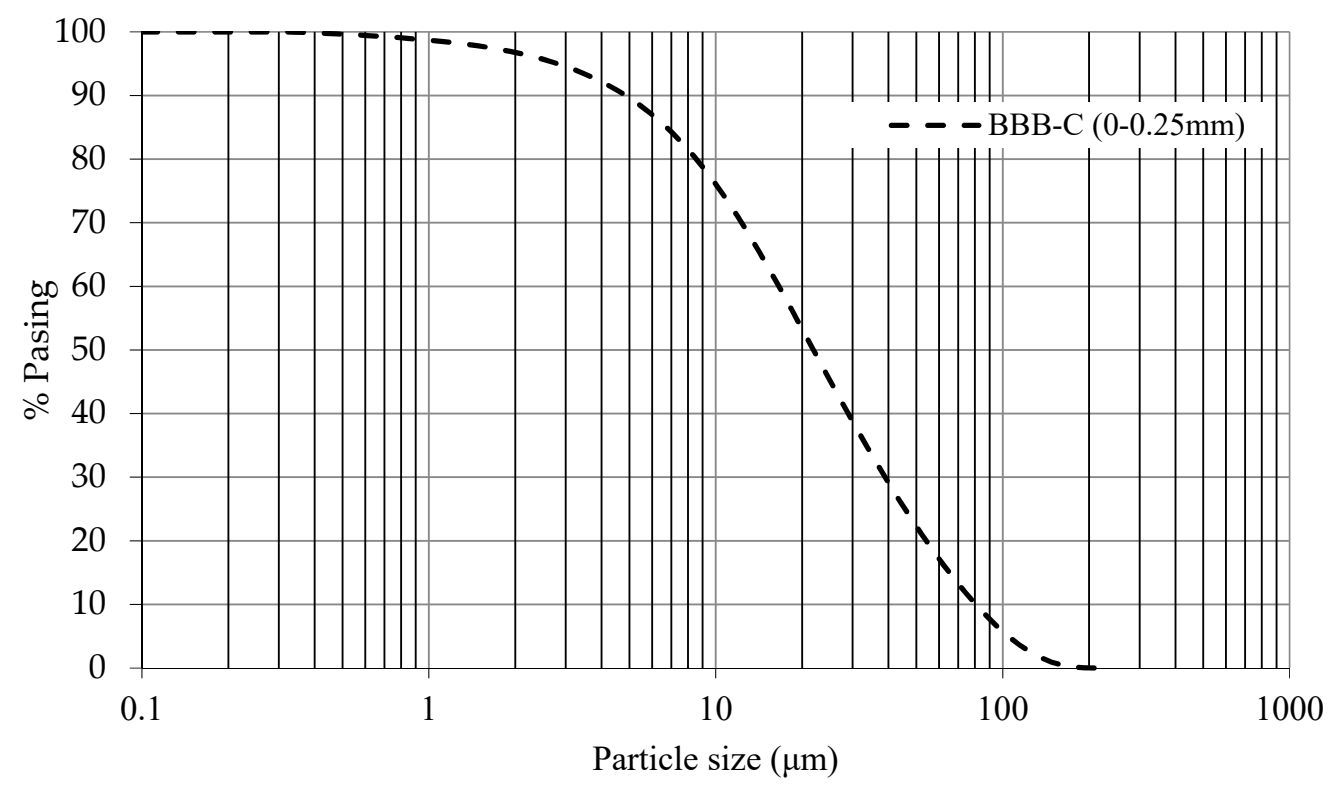

Figure 3. Particle size distribution curve of BBA-Crushed.

\section{Dosage}

The most important condition that must be considered in order to carry out the dosing of a self-compacting concrete is to provide a sufficient quantity of the set consisting of "cement + water + fines of less than $0.125 \mathrm{~mm}$ content in the aggregates" to achieve self-compacting characteristics.

Two series of dosages were carried out. The first series replaced filler with crushed biomass bottom ash (BBA-C) with a replacement of $20 \%, 40 \%$ and $60 \%$, respectively, and the second series replaced natural sand with BBA $(10 \%, 20 \%$ and $30 \%$, respectively) without any processing. The additive used was MasterGlenium ACE 325 manufactured by BASF. Dosages are shown in Table 3.

\section{Workability of the Fresh Concrete}

All the mixtures that underwent the tests indicated the current regulations (EHE-08) for the characterisation of self-compatibility: slump flow, according to EN 12350-8; V-funnel according to EN 12350-9; J-Ring according to EN 12350-12; and L-Box test according to EN 12350-10.

Slump flow: This is the simplest and most widely used method due to the simplicity of the equipment required. The value of the flow extension (Df) is useful for evaluating the deformation capacity of self-compacting concrete. Df measurements resulting between 60 and $80 \mathrm{~cm}$ are recommended, presenting mixtures in that range with good ability or ease for filling, according to EFNARC, 2002 [37].

J-Ring: This determines the ability of self-compacting concrete to flow through narrow openings, including gaps between trusses and other obstructions without segregation or blockage. After flow ceases, the final extension diameter is measured as the mean of two perpendicular diameters.

L-Box: This consists of a vertical tank that connects to a horizontal channel through an opening in which reinforcement bars are placed. The test involves filling the reservoir and allowing concrete to flow into the channel through the trusses. The time taken for the concrete to reach a distance of $200 \mathrm{~mm}$ (T20) and $400 \mathrm{~mm}$ (T40) is determined, and the heights $\mathrm{H} 1$ and $\mathrm{H} 2$ are reached at both ends of the horizontal part, with the mixture already at rest. The $\mathrm{H} 2 / \mathrm{H} 1$ ratio is defined as the blocking coefficient $(\mathrm{Cb})$.

V-funnel: This test evaluates the ability of concrete to flow in restricted areas in a vertical direction and under its own weight, qualifying the tendency with respect to segregation and blocking, by observing the variation in flow velocity. 
Table 3. Concrete mix proportions $\left(\mathrm{kg} / \mathrm{m}^{3}\right)$.

\begin{tabular}{|c|c|c|c|c|c|c|c|c|c|c|c|}
\hline \multirow{2}{*}{ Serie } & \multirow{2}{*}{ Mix Name } & \multicolumn{4}{|c|}{ Natural Aggregates } & \multicolumn{2}{|c|}{ Biomass Bottom Ash } & \multirow{2}{*}{ CEM } & \multirow{2}{*}{ Water } & \multirow{2}{*}{ W/C Relation } & \multirow{2}{*}{ Additive } \\
\hline & & NCG & NMG & NS & Filler & BBA-C & BBA & & & & \\
\hline & CONTROL & 487.62 & 151.1 & 989.3 & 185 & - & - & \multirow{3}{*}{400} & 200 & 0.5 & 3.6 \\
\hline \multirow[t]{2}{*}{ SERIE 1-SSC-BBAc } & S1-SSC-40BBA-C & 487.62 & 151.1 & 989.3 & 111 & 74 & - & & 200 & 0.5 & 8.0 \\
\hline & S1-SSC-60BBA-C & 487.62 & 151.1 & 989.3 & 74 & 111 & - & & 200 & 0.5 & 8.4 \\
\hline \multirow{3}{*}{ SERIE 2-SSC-BBA } & S2-SSC-10BBA & 487.62 & 151.1 & 890.67 & 185 & - & 98.63 & \multirow{3}{*}{400} & 200 & 0.5 & 4.8 \\
\hline & S2-SSC-20BBA & 487.62 & 151.1 & 791.44 & 185 & - & 197.86 & & 200 & 0.5 & 6.8 \\
\hline & S2-SSC-30BBA & 487.62 & 151.1 & 692.51 & 185 & - & 296.79 & & 200 & 0.5 & 7.0 \\
\hline
\end{tabular}


Table 4 shows the results of the tests carried out according to current regulations (EHE-08) for obtaining the condition of self-compacting. One can observe how all the dosages used are within the parameters imposed by the regulations, and Figure 4 shows the Slump flow test and the J-Ring.

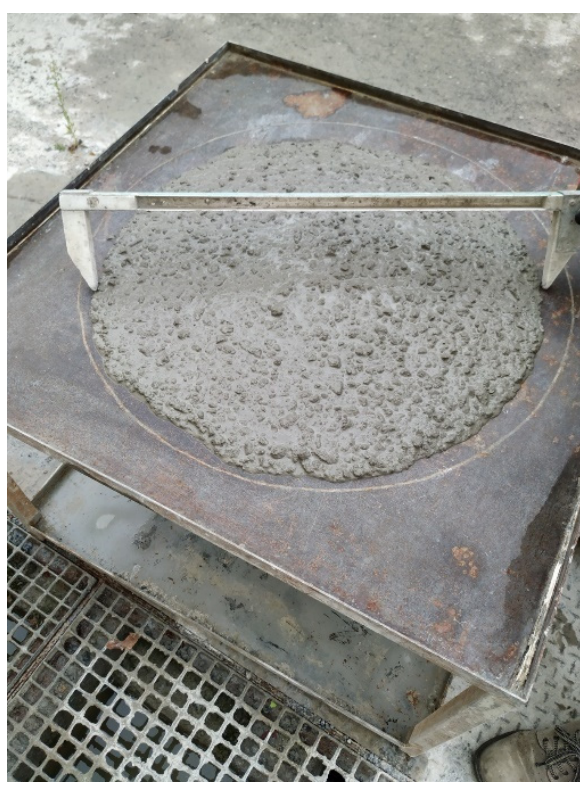

(a)

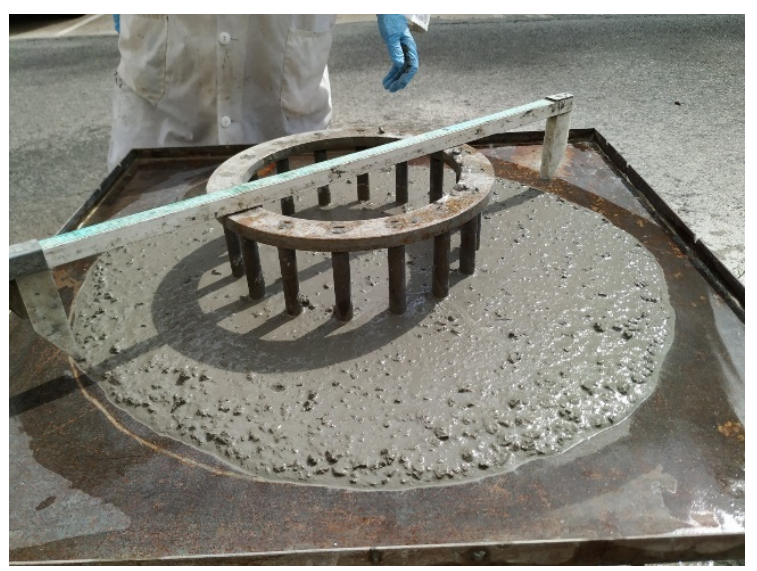

(b)

Figure 4. Results of the tests carried out according to the current regulations for considering self-compacting concrete (EHE-08). Slump flow (a) and J-Ring (b).

Table 4. Results of the tests carried out according to the current regulations for considering self-compacting concrete (EHE-08).

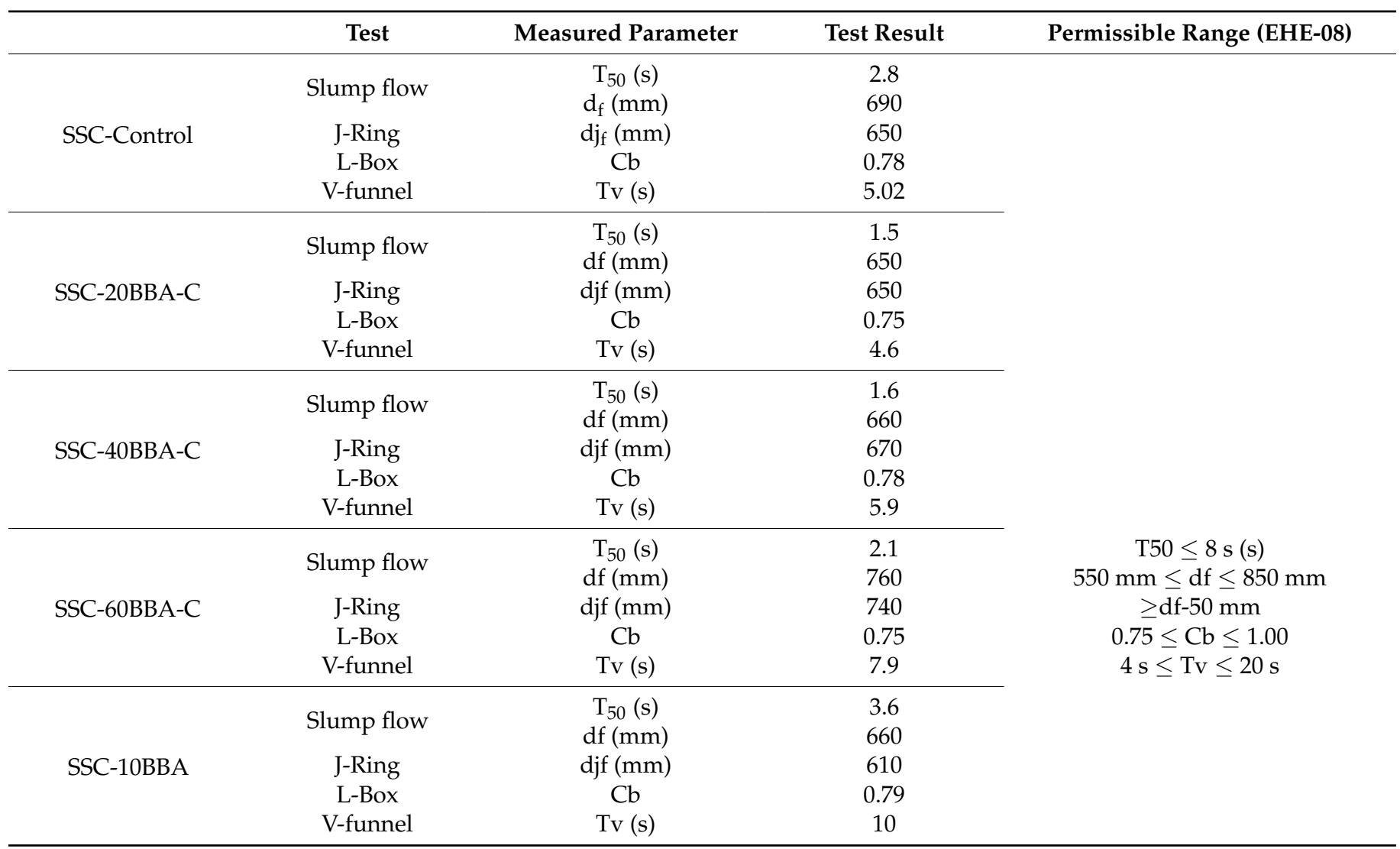


Table 4. Cont.

\begin{tabular}{|c|c|c|c|c|}
\hline & Test & Measured Parameter & Test Result & Permissible Range (EHE-08) \\
\hline \multirow{4}{*}{ SSC-20BBA } & Slump flow & $\begin{array}{c}\text { T50 (s) } \\
\text { df (mm) }\end{array}$ & $\begin{array}{c}4 \\
690\end{array}$ & \\
\hline & J-Ring & $\operatorname{djf}(\mathrm{mm})$ & 650 & \\
\hline & L-Box & $\mathrm{CbL}$ & 0.8 & \\
\hline & V-funnel & $\operatorname{Tv}(\mathrm{s})$ & 10 & \\
\hline \multirow{5}{*}{ SSC-30BBA } & & T50 (s) & 4.3 & \\
\hline & Slump flow & $\mathrm{df}(\mathrm{mm})$ & 640 & \\
\hline & J-Ring & $\operatorname{djf}(\mathrm{mm})$ & 630 & \\
\hline & L-Box & $\mathrm{CbL}$ & 0.81 & \\
\hline & V-funnel & $\operatorname{Tv}(\mathrm{s})$ & 11 & \\
\hline
\end{tabular}

\section{Experimental Methods and Results}

\subsection{Compressive Strength of Test Specimens}

The compressive strength was determined on $100 \mathrm{~mm} \times 100 \mathrm{~mm}$ cubic samples for ages 7, 28, 90 and 256 days according to EN 12390-3: 2019. Table 5 shows the values of the resistances obtained for each of the series.

Table 5. Compressive strength of SCC.

\begin{tabular}{cccccccc}
\hline & \multicolumn{7}{c}{ Compressive Strength (MPa) } \\
\hline \multicolumn{2}{c}{ Time (Days) } & $\mathbf{7}$ & $\mathbf{2 8}$ & $\mathbf{9 0}$ & $\mathbf{2 5 6}$ & INCREASING28-256 DAYS (\%) \\
\hline & CONTROL & 67.26 & 81.53 & 82.87 & 83.14 & 1.90 \\
\hline \multirow{3}{*}{ SERIE 1-SSC-BBA-C } & S1-SSC-20BBA-C & 53.06 & 59.62 & 65.76 & 72.43 & 21.48 \\
\cline { 2 - 7 } & S1-SSC-40BBA-C & 43.11 & 51.93 & 56.69 & 64.81 & 24.80 \\
\cline { 2 - 7 } & S1-SSC-60BBA-C & 38.74 & 45.21 & 49.12 & 58.67 & 29.77 \\
\hline \multirow{2}{*}{ SERIE 2-SSC-BBA } & S2-SSC-10BBA & 43.29 & 50.12 & 53.28 & 58.44 & 16.60 \\
\cline { 2 - 7 } & S2-SSC-20BBA & 37.76 & 43.51 & 47.96 & 51.27 & 17.83 \\
\cline { 2 - 7 } & S2-SSC-30BBA & 35.58 & 39.48 & 43.55 & 48.94 & 23.96 \\
\hline
\end{tabular}

The use of industrial by-products as a substitute for the fine fraction directly affects simple compressive strength [38]. Some authors focus on the substitution of coarse and fine fraction of natural aggregates, obtaining substitution ranges depending on the type of industrial by-product used [39].

In this work, ranges of $20 \%, 40 \%$ and $60 \%$ substitution of limestone filler by BBA-C (Series 1) and 10\%, 20\% and 30\% substitution of natural sand (Series 2) were proposed.

The best compressive strength results were shown for Series 1 where lime filler was replaced by BBA-C, which is essential to avoid SCC segregation.

The analysis of the 28 day compressive strength showed a reduction in all mixes combined with biomass bottom ash, a result also observed by Mehta and Monteiro and Rosales et al. $[40,41]$ However, Figure 5 shows the long-term increase in resistance. It can be observed that after 256 days, the mixes continue to gain strength approximately between $17 \%$ and $30 \%$. This behaviour could be mainly attributed to the pozzolanicity of the BBA. 


\section{Increase in compressive strength from 28 to 256 days}

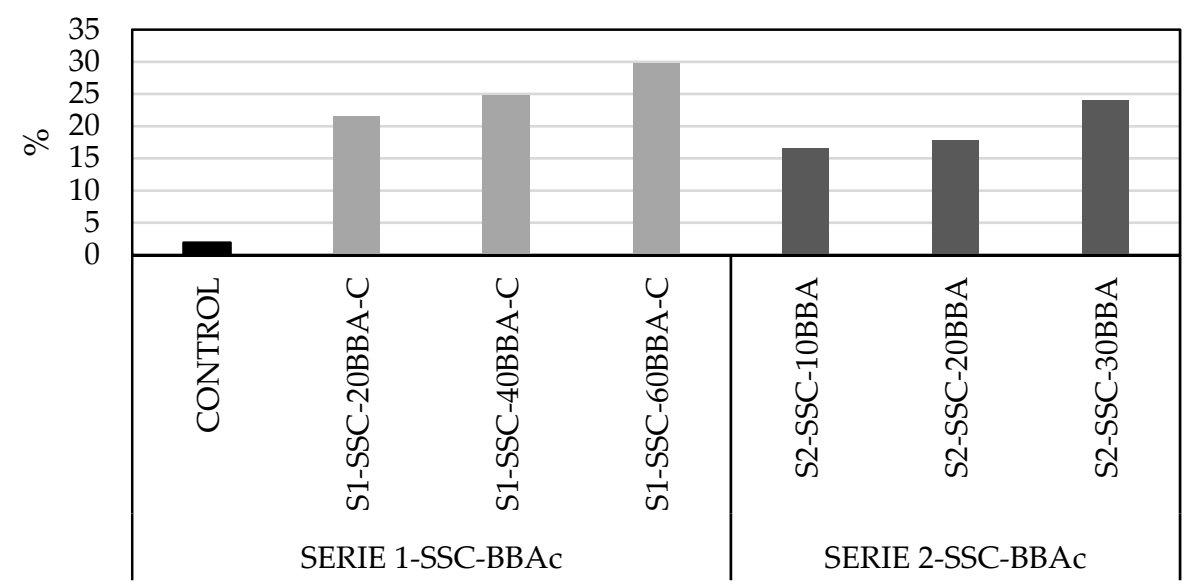

Figure 5. Comparative of increase in compressive strength from 28 to 256 days.

\subsection{Tensile Splitting Strength of Test Specimens}

This test was carried out by subjecting a $150 \times 300 \mathrm{~mm}$ cylindrical specimen cured in a humid chamber for diametric compression for 28 days in accordance with EN 12390-6: 2009. A load was applied evenly along two opposite lines until breakage was achieved. This load causes a relatively uniform tensile stress throughout the diameter of the vertical load plane, and this tension is the one that exhausts the specimen and triggers the break in the diametral plane. The values obtained are shown in Table 6.

Table 6. Tensile splitting strength and modulus of elasticity.

\begin{tabular}{cccccccc}
\hline & & \multicolumn{2}{c}{ SERIE 1-SSC-BBA-C } & \multicolumn{3}{c}{ SERIE 2-SSC-BBA } \\
\hline & CONTROL & $\begin{array}{c}\text { S1-SSC- } \\
\text { 20BBA-C }\end{array}$ & $\begin{array}{c}\text { S1-SSC- } \\
\text { 40BBA-C }\end{array}$ & $\begin{array}{c}\text { S1-SSC- } \\
\text { 60BBA-C }\end{array}$ & $\begin{array}{c}\text { S2-SSC- } \\
\text { 10BBA }\end{array}$ & $\begin{array}{c}\text { S2-SSC- } \\
\text { 20BBA }\end{array}$ & $\begin{array}{c}\text { S2-SSC- } \\
\text { 30BBA }\end{array}$ \\
\hline Tensile splitting strength $(\mathrm{MPa})$ & 8.56 & 6.08 & 5.18 & 4.15 & 4.46 & 3.65 & 3.15 \\
\hline Modulus of elasticity $(\mathrm{MPa})$ & 56,129 & 42,018 & 36,947 & 31,779 & 35,439 & 30,857 & 28,541 \\
\hline
\end{tabular}

\subsection{Determination of Modulus of Elasticity}

The modulus of elasticity of concrete represents the stiffness of this material when faced with a load imposed on it. The test for the determination of the static modulus of elasticity of concrete is carried out by means of the EN 12390-13: 2014 Standard and has as its principle the application of static load and the corresponding produced unit deformation.

The first phase (elastic zone) applied a stress of $30 \%$ of the compressive strength obtained in the previously described test. In the second phase (curved line), the concrete specimen is submitted to breakage according to the regulations. The results are shown in Table 6.

Regarding the tensile splitting strength, the trend of the experimental data tends to guarantee the existing relationship between compression and traction in concrete. Tensile splitting strength values were observed in the concrete representing approximately $10-15 \%$ of the results obtained for compressive strength.

In order to observe the relationship between tensile splitting strength and the modulus of elasticity, a trend is proposed which aims to observe the behaviour of these two variables (Figure 6). 


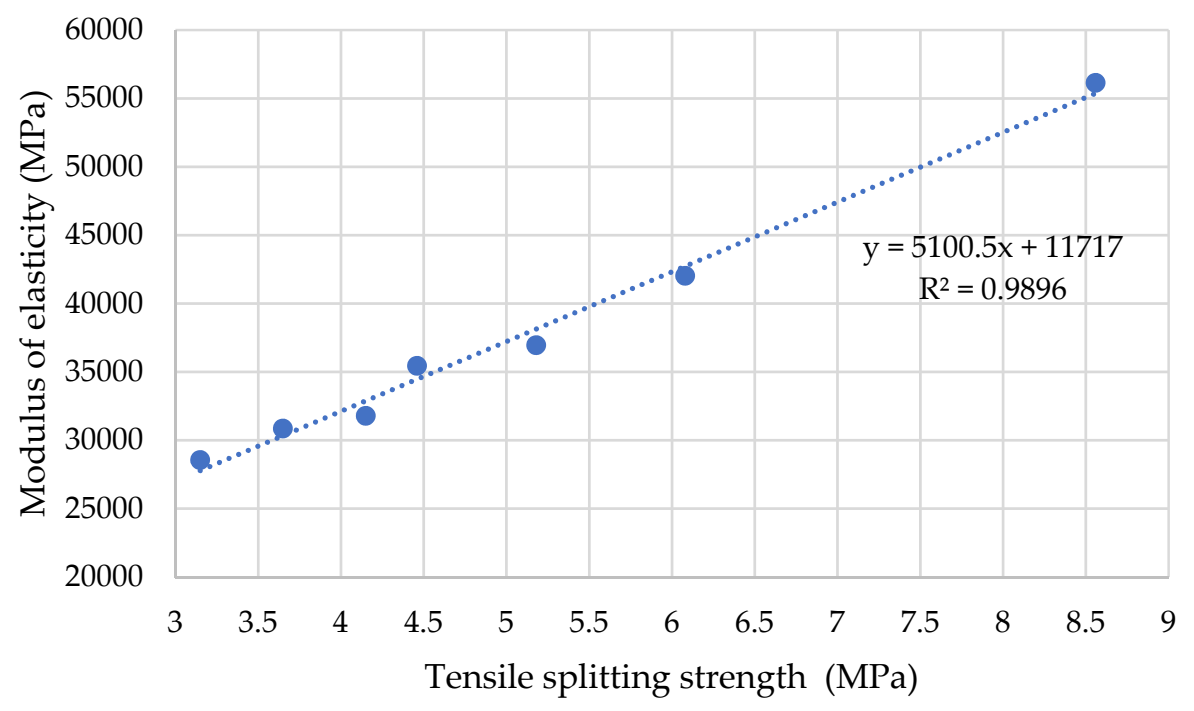

Figure 6. Relationship between tensile splitting strength and modulus of elasticity.

The modulus of elasticity ranged from $42.01 \mathrm{GPa}$ to $31.77 \mathrm{GPa}$ for Series 1 and between 35.43 GPa and 28.54 GPa for Series 2. These results demonstrate that the manufactured concrete can be suitable for many structural applications, even for structures with demanding limitations regarding serviceability limit states (e.g., deformations and deflections) [42].

\subsection{Density and Absorption of Hardened Concrete}

The density and absorption percentage were determined in specimens of hardened SCC. Each series was subjected to a cycle of immersion in water for $24 \mathrm{~h}$ and subsequently to oven drying between $105^{\circ} \mathrm{C}$ and $110^{\circ} \mathrm{C}$ for $24 \mathrm{~h}$. With this procedure, the apparent mass in the water, the saturated mass with a dry surface and the dry mass are obtained, and the density and supply are obtained with these data in accordance with the EN 12390-7: 2019 standard (Testing hardened concrete—Part 7: Density of hardened concrete). The test results are shown in Table 7.

Table 7. Density and absorption of hardened concrete.

\begin{tabular}{cccccccc}
\hline & & \multicolumn{3}{c}{ SERIE 1-SSC-BBA-C } & \multicolumn{3}{c}{ SERIE 2-SSC-BBA } \\
\hline & CONTROL & $\begin{array}{c}\text { S1-SSC- } \\
\text { 20BBA-C }\end{array}$ & $\begin{array}{c}\text { S1-SSC- } \\
\text { 40BBA-C }\end{array}$ & $\begin{array}{c}\text { S1-SSC- } \\
\text { 60BBA-C }\end{array}$ & $\begin{array}{c}\text { S2-SSC- } \\
\text { 10BBA }\end{array}$ & $\begin{array}{c}\text { S2-SSC- } \\
\text { 20BBA }\end{array}$ & $\begin{array}{c}\text { S2-SSC- } \\
\text { 30BBA }\end{array}$ \\
\hline Density $\left(\mathrm{Kg} / \mathrm{dm}^{3}\right)$ & 2.46 & 2.44 & 2.41 & 2.38 & 2.39 & 2.35 & 2.33 \\
\hline Absorption $(\%)$ & 5.74 & 6.22 & 6.39 & 6.8 & 7.12 & 7.48 & 7.92 \\
\hline
\end{tabular}

The results show how the incorporation of BBA decreases density and increases absorption in all the mixtures (Figure 7). Density directly depends on the density of the materials used to manufacture the concrete. In both series, the maximum BBA substitution corresponds to the lowest density and highest absorption values, and this is due to the fact that BBAs have a very porous structure in agreement with other authors [31,41].

\subsection{Penetration of Water under Pressure}

The depth of water penetration under pressure was determined in $150 \times 300 \mathrm{~mm}$ cylindrical specimens cured in a humidity chamber for 28 days. The water was applied under pressure of $500 \mathrm{kPa}$ for $72 \mathrm{~h}$. Subsequently, the test piece was divided by breaking it into two halves, and the penetration of the waterfront was recorded in accordance with the EN 12390-8:2019 standard. The results are shown in Table 8. 


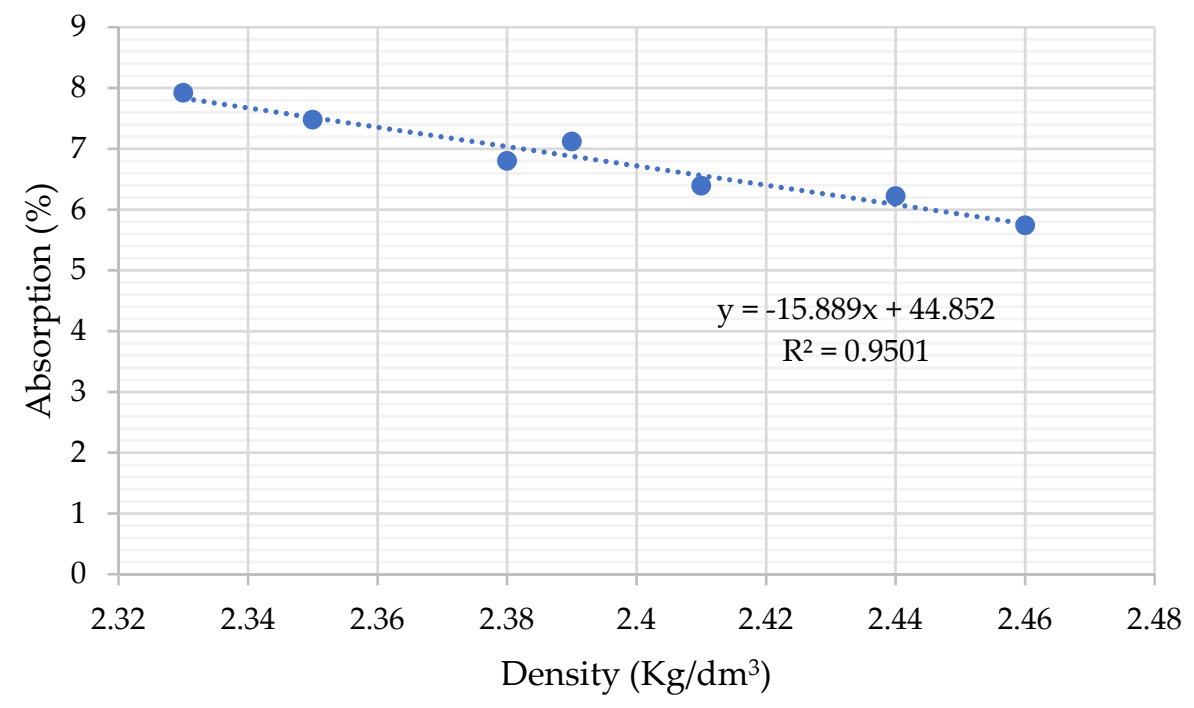

Figure 7. Relationship between density and absorption.

Table 8. Penetration of water under pressure (mm).

\begin{tabular}{cccccccc}
\hline & & \multicolumn{2}{c}{ SERIE 1-SSC-BBA-C } & \multicolumn{3}{c}{ SERIE 2-SSC-BBA } \\
\hline & CONTROL & $\begin{array}{c}\text { S1-SSC- } \\
\text { 20BBA-C }\end{array}$ & $\begin{array}{c}\text { S1-SSC- } \\
\text { 40BBA-C }\end{array}$ & $\begin{array}{c}\text { S1-SSC- } \\
\text { 60BBA-C }\end{array}$ & $\begin{array}{c}\text { S2-SSC- } \\
\text { 10BBA }\end{array}$ & $\begin{array}{c}\text { S2-SSC- } \\
\text { 20BBA }\end{array}$ & $\begin{array}{c}\text { S2-SSC- } \\
\text { 30BBA }\end{array}$ \\
\hline $\begin{array}{l}\text { Penetration of water } \\
\text { under pressure (mm) }\end{array}$ & 3.12 & 5.37 & 6.89 & 7.54 & 6.57 & 8.15 & 9.87 \\
\hline
\end{tabular}

Structural Concrete Instruction (EHE08) uses the determination of water penetration depth as a verifier that the concrete has sufficient impermeability to ensure durability during the service life of the structure.

The limits of the Structural Concrete Instruction are set at $50 \mathrm{~mm}$ for maximum depth and $30 \mathrm{~mm}$ for the average depth in mass or reinforced concrete.

As shown in Table 8, the differently manufactured concrete did not exceed the established limits. The higher water penetration values correspond to the higher BBA replacement rate, mainly due to the high porosity of the BBA [26].

\subsection{Carbonatation Depth}

Carbonation is a process of chemical origin that consists of the combination of $\mathrm{CO}_{2}$ with concrete portlandite. In order to know the degree of carbonation, the specimens were subjected to a $\mathrm{CO}_{2}$ saturated environment according to UNE 112011:2011 (relative humidity $55-65 \%$, a temperature of $23 \pm 3{ }^{\circ} \mathrm{C}$ and an air supply with $\left.5 \pm 0.1 \% \mathrm{CO}_{2}\right)$. To carry out the test, a piece of concrete was broken from each of the specimens, then the phenolphthalein solution was applied to the concrete. A colour change (pink) on the application surface will indicate that the concrete is not carbonated. If the colouration does not occur, it means that it is an area that is already carbonated.

From a chemical point of view, the carbonation of concrete produces a decrease in $\mathrm{pH}$, which occurs when $\mathrm{CO}_{2}$ penetrates through the capillary pore network reacting with the moisture present and converting calcium hydroxide (high $\mathrm{pH}$ ) to carbonates, which are neutral, reducing the alkalinity of the concrete. From a physical point of view, the carbonation of concrete depends directly on the porosity and permeability of the concrete, as well as the environmental conditions to which it is exposed [43]. Most carbonation models consider the amount of cement as an important parameter to be considered because of its strong influence on the reaction of $\mathrm{CO}_{2}$ with the $\mathrm{Ca}(\mathrm{OH}) 2$ formed during cement hydration. Figure 8 shows the evolution over time of the carbonation of the concrete studied. According to the literature [44], the mixes with the highest porosity are also 
those with the highest carbonation, and the mix with a $30 \%$ substitution of BBA by sand (S2-SSC-30BBA) is the one that shows the highest carbonation front.

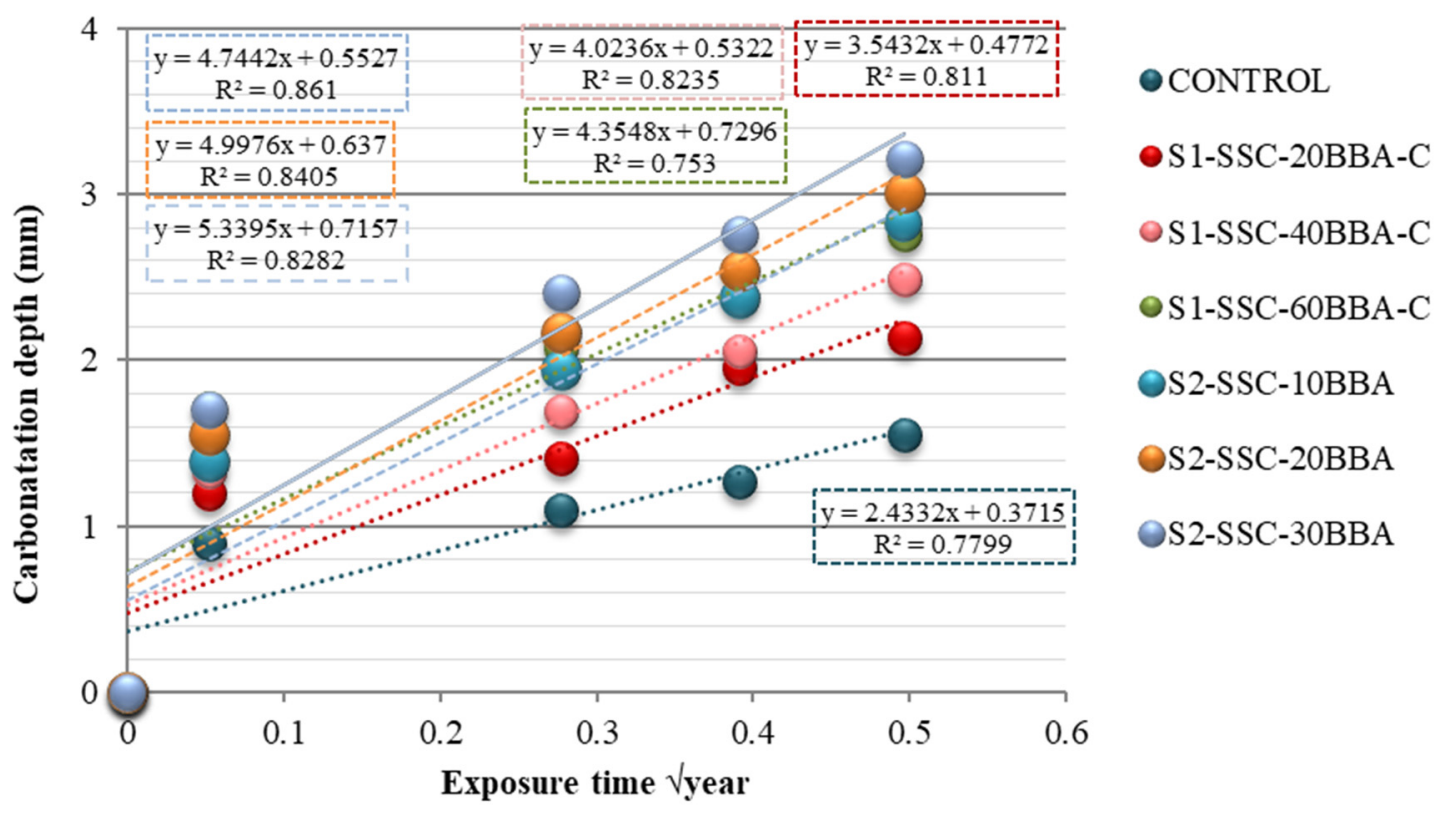

Figure 8. Relationship between carbonatation depth and exposure time.

\section{Conclusions}

This study has evaluated the properties of biomass bottom ash with different treatments applied and the influence that its use has on the mechanical and durability properties in the manufacture of self-compacting concrete.

The following conclusions were obtained:

- An important factor in the physical properties of BBAs is their high absorption and low density $\left(19.83 \%\right.$ and $1.73 \mathrm{~g} / \mathrm{cm}^{3}$, respectively). Both parameters are important in the design of mixtures where the presence of water and the volume of material is a conditioning factor for its manufacture.

- The presence of $\mathrm{K}_{2} \mathrm{O}$ in cementitious materials can reduce durability due to deterioration of the microstructure. However, the $\mathrm{Si} / \mathrm{Ca}$ values of the mixture provide increased mechanical strength due to their pozzolanic character.

- In relation to the mechanical properties, compressive strength, tensile splitting strength and modulus of elasticity are reduced for all mixes combined with biomass bottom ash. However, the mixtures combined with biomass bottom ash still gain $17-30 \%$ in long-term compressive strength compared to the control mixtures.

- In terms of durability parameters, water penetration under pressure is higher when biomass bottom ash is incorporated with sand due to the larger particle size and high porosity of the mixture.

- The depth of carbonation of concrete depends on many variables, and the most important ones are porosity and permeability. Mixtures with higher porosity and permeability are also those with higher carbonation.

In conclusion, the use of self-compacting concretes with the substitution of up to $30 \%$ of natural sand by screened BBA and up to $60 \%$ of filler by crushed BBA is recommended for use in civil infrastructure works. The valorisation of biomass bottom ash instead of exploiting natural or non-renewable resources can eliminate the negative impact associated with indiscriminate disposal of this by-product in landfills. 
Author Contributions: Conceptualization, M.C. and F.A.; methodology, M.L.-A. and M.J.M.-E.; formal analysis, J.R. and M.C.; investigation, M.C., M.L.-A. and M.J.M.-E.; resources, F.A. and M.C.; data curation, J.R. and M.C.; writing-original draft preparation, M.C.; writing-review and editing, J.R. and M.C.; visualization, F.A. and M.J.M.-E.; supervision, M.C.; project administration, F.A. All authors have read and agreed to the published version of the manuscript.

Funding: FEDER/ Ministry of Science, Innovation and Universities-Agencia Estatal de Investigación (State Research Agency)/Valorisation of biomass bottom ash for sustainable construction applications (1264457-R)—BIOCEM.

Acknowledgments: The authors would like to thank Professor José Rodriguez Montero for sharing all his knowledge, time and work.

Conflicts of Interest: The authors declare no conflict of interest.

\section{Appendix A}

Standards used in the experimental work are as follows:

EN 1097-6:2014. Tests for mechanical and physical properties of aggregates-Part 6: Determination of particle density and water absorption.

EN 146404: 2018. Aggregates for concrete determination of the coefficient of friability of the sands.

EN 933-8:2012. Tests for geometrical properties of aggregates-Part 8: Assessment of fines-Sand equivalent test.

EN ISO 17892-12:2019. Geotechnical investigation and testing-Laboratory testing of soil-Part 12: Determination of liquid and plastic limits (ISO 17892-12:2018).

EN 1744-1:2010. Tests for chemical properties of aggregates-Part 1: Chemical analysis.

UNE 103204:2019. Organic matter content of a soil by the potassium permanganate method.

UNE -EN 196-2:2014. Method of testing cement-Part 2: Chemical analysis of cement.

Real Decreto 1247/2008, de 18 de julio, por el que se aprueba la instrucción de hormigón estructural (EHE-08), Boletín Oficial del Estado, núm. 203, de 22 de agosto de 2008, pp. 35176 a 35178.

UNE-EN 12350-8:2011. Testing fresh concrete-Part 8: Self-compacting concreteSlump-flow test.

UNE-EN 12350-9:2011. Testing fresh concrete-Part 9: Self-compacting concrete-Vfunnel test.

UNE-EN 12350-10:2011. Testing fresh concrete-Part 10: Self-compacting concrete-L box test.

UNE 12350-12:2011. Testing fresh concrete-Part 12: Self-compacting concrete-J-ring test.

UNE 12390-3:2019. Testing hardened concrete-Part 3: Compressive strength of test specimens.

UNE 12390-6:2010. Testing hardened concrete—Part 6: Tensile splitting strength of test specimens.

EN 12390-13:2014. Testing hardened concrete-Part 13: Determination of secant modulus of elasticity in compression.

EN 12390-7:2019. Testing hardened concrete-Part 7: Density of hardened concrete.

EN 12390-8:2019. Testing hardened concrete-Part 8: Depth of penetration of water under pressure.

UNE 112011:2011. Corrosion of concrete reinforcement steel. Determination of the carbonatation depth for in-service concrete.

\section{References}

1. Okamura, H. Self-compacting high-performance concrete. Concr. Int. 1997, 19, 50-54.

2. Khayat, K.H. Use of Self-Consolidating Concrete in Canada. In Proceedings of the International Workshop on Self-Compacting Concrete, Kochi, Japan, 23-26 August 1998; Volume 23, p. 26.

3. Ernst, F.M.L. Onderzoek Zelfverdichtend Beton. MSc Thesis, TUE/CCO/00-09, Capaciteitsgroep Constructief Ontwerpen, Faculteit Bouwkunde, Eindhoven University of Technology, Eindhoven, The Netherlands, 2000. (In Dutch). 
4. Su, N.; Hsu, K.C.; Chai, H.W. A simple mix design method for self-compacting concrete. Cement Concr. Res. 2001, 31, $1799-1807$. [CrossRef]

5. Langley, W.S.; Carette, G.G.; Malhotra, V.M. Structural concrete incorporating high volumes of ASTM class fly ash. Mater. J. 1989, $86,507-514$.

6. Li, G.; Zhao, X. Properties of concrete incorporating fly ash and ground granulated blast-furnace slag. Cem. Concr. Compos. 2003, 25, 293-299. [CrossRef]

7. Li, G. Properties of high-volume fly ash concrete incorporating nano-SiO 2 . Cem. Concr. Res. 2004, 34, 1043-1049. [CrossRef]

8. Sabet, F.A.; Libre, N.A.; Shekarchi, M. Mechanical and durability properties of self-consolidating high performance concrete incorporating natural zeolite, silica fume and fly ash. Constr. Build. Mater. 2013, 44, 175-184. [CrossRef]

9. Patil, B.B.; Kumbhar, P.D. Strength and durability properties of high performance concrete incorporating high reactivity metakaolin. Int. J. Mod. Eng. Res. 2012, 2, 1099-1104.

10. Persson, B. A comparison between mechanical properties of self-compacting concrete and the corresponding properties of normal concrete. Cem. Concr. Res. 2001, 31, 193-198. [CrossRef]

11. Mebrouki, A.; Belas, N.; Bendani, K.; Bouhamou, N. A self-compacting cement paste formulation using mixture design. J. Appl. Sci. 2009, 9, 4127-4136. [CrossRef]

12. Concha, N.C.; Calilung, M.G.V. Investigation on the effects of blended admixtures on workability of self-compacting concrete. In Proceedings of the 2017 IEEE 9th International Conference on Humanoid, Nanotechnology, Information Technology, Communication and Control, Environment and Management (HNICEM), Manila, Philippines, 1-3 December 2017; pp. 1-6.

13. Bignozzi, M.C.; Sandrolini, F. Tyre rubber waste recycling in self-compacting concrete. Cem. Concr. Res. 2006, 36, 735-739. [CrossRef]

14. Ali, E.E.; Al-Tersawy, S.H. Recycled glass as a partial replacement for fine aggregate in self compacting concrete. Constr. Build. Mater. 2012, 35, 785-791. [CrossRef]

15. Ghernouti, Y.; Rabehi, B.; Bouziani, T.; Ghezraoui, H.; Makhloufi, A. Fresh and hardened properties of self-compacting concrete containing plastic bag waste fibers (WFSCC). Constr. Build. Mater. 2015, 82, 89-100. [CrossRef]

16. González-Taboada, I.; González-Fonteboa, B.; Martínez-Abella, F.; Seara-Paz, S. Analysis of rheological behaviour of selfcompacting concrete made with recycled aggregates. Constr. Build. Mater. 2017, 157, 18-25. [CrossRef]

17. Pereira-de-Oliveira, L.A.; Nepomuceno, M.C.S.; Castro-Gomes, J.P.; Vila, M.D.F.C. Permeability properties of self-compacting concrete with coarse recycled aggregates. Constr. Build. Mater. 2014, 51, 113-120. [CrossRef]

18. Kou, S.C.; Poon, C.S. Properties of self-compacting concrete prepared with coarse and fine recycled concrete aggregates. Cem. Concr. Compos. 2009, 31, 622-627. [CrossRef]

19. Calvo, J.G.; Hidalgo, A.; Alonso, M.C.; Luxán, M.P.; Luco, L.F. Caracterización de residuos procedentes de los procesos de combustión de biomasa viabilidad de uso como materiales de construcción. In Proceedings of the XI Congreso Nacional de Materiales Zaragoza, Zaragoza, Spain, 23-25 June 2010.

20. Nogales, R.; Delgado, G.; Quirantes, M.; Romero, M.; Romero, E.; Molina-Alcaide, E. Characterization of olive waste ashes as fertilizers. In Recycling of Biomass Ashes; Springer: Berlin/Heidelberg, Germany, 2011; pp. 57-68.

21. Omil, B.; Sánchez-Rodríguez, F.; Merino, A. Effects of ash applications on soil status, nutrition, and growth of Pinus radiata D. Don Plantations. In Recycling of Biomass Ashes; Springer: Berlin/Heidelberg, Germany, 2011; pp. 69-86.

22. Maschio, S.; Tonello, G.; Piani, L.; Furlani, E. Fly and bottom ashes from biomass combustion as cement replacing components in mortars production: Rheological behaviour of the pastes and materials compression strength. Chemosphere 2011, 85, 666-671. [CrossRef]

23. Modolo, R.C.E.; Ferreira, V.M.; Tarelho, L.A.; Labrincha, J.A.; Senff, L.; Silva, L. Mortar formulations with bottom ash from biomass combustion. Constr. Build. Mater. 2013, 45, 275-281. [CrossRef]

24. Beltrán, M.G.; Barbudo, A.; Agrela, F.; Jiménez, J.R.; de Brito, J. Mechanical performance of bedding mortars made with olive biomass bottom ash. Constr. Build. Mater. 2016, 112, 699-707. [CrossRef]

25. Rosales, J.; Cabrera, M.; Beltrán, M.G.; López, M.; Agrela, F. Effects of treatments on biomass bottom ash applied to the manufacture of cement mortars. J. Clean. Prod. 2017, 154, 424-435. [CrossRef]

26. Cabrera, M.; Agrela, F.; Ayuso, J.; Galvin, A.P.; Rosales, J. Feasible use of biomass bottom ash in the manufacture of cement treated recycled materials. Mater. Struct. 2016, 49, 3227-3238. [CrossRef]

27. Cabrera, M.; Rosales, J.; Ayuso, J.; Estaire, J.; Agrela, F. Feasibility of using olive biomass bottom ash in the sub-bases of roads and rural paths. Constr. Build. Mater. 2018, 181, 266-275. [CrossRef]

28. Beltrán, M.G.; Agrela, F.; Barbudo, A.; Ayuso, J.; Ramírez, A. Mechanical and durability properties of concretes manufactured with biomass bottom ash and recycled coarse aggregates. Constr. Build. Mater. 2014, 72, 231-238. [CrossRef]

29. Agrela, F.; Beltran, M.G.; Cabrera, M.; López, M.; Rosales, J.; Ayuso, J. Properties of recycled concrete manufacturing with all-in recycled aggregates and processed biomass bottom ash. Waste Biomass Valoriz. 2018, 9, 1247-1259. [CrossRef]

30. Khan, A.A.; De Jong, W.; Jansens, P.J.; Spliethoff, H. Biomass combustion in fluidized bed boilers: Potential problems and remedies. Fuel Process. Technol. 2009, 90, 21-50. [CrossRef]

31. Cabrera, M.; Galvin, A.P.; Agrela, F.; Carvajal, M.D.; Ayuso, J. Characterisation and technical feasibility of using biomass bottom ash for civil infrastructures. Constr. Build. Mater. 2014, 58, 234-244. [CrossRef] 
32. Hinojosa, M.J.R.; Galvín, A.P.; Agrela, F.; Perianes, M.; Barbudo, A. Potential use of biomass bottom ash as alternative construction material: Conflictive chemical parameters according to technical regulations. Fuel 2014, 128, 248-259. [CrossRef]

33. Melotti, R.; Santagata, E.; Bassani, M.; Salvo, M.; Rizzo, S. A preliminary investigation into the physical and chemical properties of biomass ashes used as aggregate fillers for bituminous mixtures. Waste Manag. 2013, 33, 1906-1917. [CrossRef] [PubMed]

34. Munkholm, L.J. Soil friability: A review of the concept, assessment and effects of soil properties and management. Geoderma 2011, 167, 236-246. [CrossRef]

35. Huang, Y.; McMullan, J.T.; Williams, B.C. Influences of coal type on the performance of a pressurised fluidised bed combustion power plant. Fuel 2000, 79, 1595-1601. [CrossRef]

36. Modolo, R.C.E.; Silva, T.; Senff, L.; Tarelho, L.A.C.; Labrincha, J.A.; Ferreira, V.M.; Silva, L. Bottom ash from biomass combustion in BFB and its use in adhesive-mortars. Fuel Process. Technol. 2015, 129, 192-202. [CrossRef]

37. Efnarc, S. Guidelines for Self-Compacting Concrete; Association House: London, UK, 2002; Volume 32, p. 34.

38. Corinaldesi, V.; Moriconi, G. Influence of mineral additions on the performance of $100 \%$ recycled aggregate concrete. Constr. Build. Mater. 2009, 23, 2869-2876. [CrossRef]

39. Tiwari, A.; Singh, S.; Nagar, R. Feasibility assessment for partial replacement of fine aggregate to attain cleaner production perspective in concrete: A review. J. Clean. Prod. 2016, 135, 490-507. [CrossRef]

40. Mehta, P.K.; Monteiro, P.J.; Concrete-Microstructure, P. Materials; Mc Graw Hill: New York, NY, USA, 2006 ; pp. 85-86.

41. Rosales, J.; Beltrán, M.G.; Cabrera, M.; Velasco, A.; Agrela, F. Feasible use of biomass bottom ash as addition in the manufacture of lightweight recycled concrete. Waste Biomass Valorize 2016, 7, 953-963. [CrossRef]

42. Skarendahl, Å.; Petersson, Ö. (Eds.) Report 23: Self-Compacting Concrete-State-of-the-Art Report of Rilem Technical Committee 174-SCC; RILEM Publications: Moscow, Russia, 2000; Volume 23.

43. Bertolini, L.; Elsener, B.; Pedeferri, P.; Redaelli, E.; Polder, R.B. Corrosion of Steel in Concrete: Prevention, Diagnosis, Repair; John Wiley \& Sons: Hoboken, NJ, USA, 2013.

44. Rosales, J.; Agrela, F.; Díaz-López, J.L.; Cabrera, M. Alkali-Activated Stainless Steel Slag as a Cementitious Material in the Manufacture of Self-Compacting Concrete. Materials 2021, 14, 3945. [CrossRef] [PubMed] 